\title{
AKADEMSKO, SOCIJALNO I EMOCIONALNO FUNKCIONIRANJE DJECE SUSPEKTNE NA ADHD ${ }^{1}$
}

\author{
Tena Velki \\ Fakultet za odgojne i obrazovne znanosti \\ Sveučilište J. J. Strossmayera u Osijeku \\ Cara Hadrijana 10, 31000 Osijek \\ tena.velki@gmail.com \\ Ksenija Romstein \\ Fakultet za odgojne i obrazovne znanosti \\ Sveučilište J. J. Strossmayera u Osijeku \\ Cara Hadrijana 10, 31000 Osijek \\ kromstein@ffoozos.hr
}

\begin{abstract}
Sažetak
Brojna su istraživanja pokazala kako djeca s ADHD-om pokazuju probleme $\mathrm{u}$ akademskom, socijalnom i emocionalnom funkcioniranju. Međutim, jako mali broj istraživanja bavi se djecom koja su suspektna na ADHD-a, a gdje bi ovakva odstupanja mogla uputiti na posljedični razvoj poremećaja te kao takva biti važna u organizaciji preventivnih programa. Cilj istraživanja je provjeriti akademsko (školski uspjeh, akademska samoefikasnost), socijalno (broj prijatelja, vršnjačka prihvaćenost, socijalna samoefikasnost) i emocionalno (empatija, emocionalna kompetentnost, emocionalna samoefikasnost) funkcioniranje djece suspektne na ADHD. U istraživanju su sudjelovala 492 učenika 4., 6. i 8. razreda osnovne škole (prosječne dob $M=12,72$, $\mathrm{SD}=1,62)$. Učenici su podijeljeni u 3 skupine s obzirom na samoprocjenu simptoma prema kriterijima DSM-V, pri čemu je $11 \%(\mathrm{~N}=55)$ učenika samoprocijenilo da je suspektno za razvoj ADHD-a, a 13,6\% $(\mathrm{N}=68)$ da ima simptome za dijagnozu ADHD-a te su obje ove skupine smatrane suspektnima na ADHD, dok su ostali učenici procijenili da nemaju simptome ADHD $(75,4 \%, \mathrm{~N}=377)$. Korišteni su sljedeći instrumenti: Skala hiperaktivnosti-impulzivnosti-pažnje (HIP; Vulić-Prtorić, 2006), Upitnik samoefikasnosti za djecu (SEQ-C, Vulić-Prtorić i Sorić, 2006), Upitnik emocionalne kompetentnosti (UEK-45; Takšić, 2002), Skala emocionalne empatije iz E-upitnika (Raboteg-Šarić, 2002), te su učenici pitani da procjene koliko se osjećaju prihvaćeno
\end{abstract}

1 Rezultati ovog rada dio su šireg projekta "Konstrukcija interakcijskog modela ADHD-a: identifikacija čimbenika prilagodbe na školsko okruženje učenika osnovnoškolske dobi suspektnih na ADHD” odobrenog od strane Sveučilišta J. J. Strossmayera u Osijeku 2015. godine. 
od strane vršnjaka, koliko imaju prijatelju i daju podatke o školskom uspjehu. Rezultati istraživanja pokazali su kako je kod djece suspektne na ADHD-a narušeno akademsko funkcioniranje (oba aspekta, $F_{(2,490)}$ školski uspjeh $=3,87, p=0,021, \omega$ $=0,11 ; F_{(2,490)}$ akademska samoefikasnost $\left.=23,46, p=0,000, \omega=0,29\right)$, međutim za socijalno i emocionalno funkcioniranje nađena su odstupanja samo na jednom aspektu $\left(F_{(2,490)}\right.$ vršnjačka prihvaćenost $=4,35, p=0,013, \omega=0,12 ; F_{(2,490)}$ emocionalna samoefikasnost $=6,76, p=0,001, \omega=0,15)$. Možemo zaključiti kako je kod djece suspektne na ADHD-a svakako narušeno akademsko funkcioniranje, no kada govorimo o socijalnom i emocionalnom funkcioniranju ove razlike su manje i odnose se samo na neke ispitane aspekte što bi se trebalo detaljnije ispitati u budućim istraživanjima. Budući prevencijski programi trebali bi se usmjeriti prvenstveno na pomoć u školskoj prilagodbi, ali i u razvoju socijalnih vještina potrebnih za stvaranje prisnih vršnjačkih odnosa te na razvoj djetetovih sposobnosti nošenja s negativnim emocijama.

Ključne riječi: ADHD, akademsko funkcioniranje, socijalni razvoj, emocionalni razvoj, osnovnoškolci

\section{UVOD}

Djeca kojoj je dijagnosticiran deficit pažnje/hiperaktivni poremećaj (ADHD) imaju narušeno funkcioniranje kod kuće i u školi, gdje se javljaju problemi u praćenju nastave te problemi u vršnjačkoj interakciji. Defoe, Farrington i Loeber (2013) u longitudinalnom istraživanju pronalaze kako su nisko akademsko postignuće, nemogućnost emocionalne samoregulacije i hiperaktivnost povezani s pojavom delinkventnih oblika ponašanja i posljedično, nižom kvalitetom života u odrasloj dobi. Zbog toga djeca s dijagnozom ADHD-a spadaju u rizičnu skupinu djece za razvoj niza problema, od kojih dominiraju teškoće na području akademske, socijalne $i$ emocionalne prilagodbe.

Brojne su studije potvrdile da djeca s ADHD-om, bez obzira na prosječne ili čak iznadprosječne intelektualne sposobnosti, imaju lošiji školski uspjeh, niže rezultate na standardiziranim mjerama postignuća, izvještavaju o više akademskih problema, te je manje vjerojatno da će završiti srednju školu i nastaviti obrazovanje nakon srednje za razliku od vršnjaka koji nemaju ADHD (DuPaul i Langberg, 2015; Frazier, Youngstrom, Glutting i Watkins, 2007; Weyandt i DuPaul, 2008; Wu i Gau, 2013). Istraživanja djece suspektne na ADHD pokazala su kako su ova djeca u većem riziku za lošiji školskih uspjeh u odnosu na kontrolnu skupinu djece, štoviše tijekom dvogodišnjeg praćenje kod djece suspektne na ADHD dolazi do značajnog opadanja školskog uspjeha (Bussing, Mason, Bell, Porter i Garvan, 2010), a također učenici suspektni na ADHD imaju i više izostanka (Norén Selinus i sur., 2016). August, Ostrander i Bloomquist (1992) su utvrdili kako djeca suspektna na ADHD postižu bolji školski uspjehu svim domenama (čitanje, pisanje, materinji jezik i matematika) u usporedbi sa svojim vršnjacima koji imaju dijagnosticiran ADHD, ali su lošiji u usporedbi s vršnjacima bez dijagnoze ADHD-a. ADHD negativno utječe na akademski uspjeh učenika jer uzrokuje poteškoće s pamćenjem, izvršnim 
funkcijama, samoregulacijom i koncentracijom (Turnbull, Turnbull i Wehmeyer, 2010). Djeca suspektna na ADHD pokazuju značajno lošije rezultate na testovima izvršnih funkcija, u usporedbi s vršnjacima koji nemaju ADHD, iako su im rezultati nešto bolji u odnosu na vršnjake s dijagnozom ADHD-a (Hong i sur., 2014). Učenicima s ADHD-om posebno je teško održavati pažnju, a što se pokazalo kao najbolji prediktor njihova prosjeka ocjena (Weyandt i DuPaul, 2008). Učenici s ADHD-om, posebice predominantno nepažljivim tipom, imaju veću vjerojatnost odustajanja od srednje škole, pokazujući da nepažnja može biti jedinstven faktor rizika za odustajanje od završetka srednje škole (Pagani, Vitaro, Tremblay, McDuff, Japel i Larose, 2008). Istraživanje koje su proveli Fergusson, Boden i Horwood (2010) pokazalo je kako je najviše učenika s dijagnozom ADHD-a odustalo od školovanja te nije uspjelo dobiti diplomu do 25. godine života, a iza njih su odmah slijedili učenici suspektni na ADHD. Osim nepažnje i problemi sa simptomima impulzivnosti pouzdano predviđaju niži prosjek ocjena (Frazier i sur., 2007). Dodatne studije su otkrile da i do 70\% učenika s ADHD-om ima komorbiditet s nekom od poteškoća u učenju (Mayes, Calhoun i Crowell, 2000), što im otežava nastavak školovanja. Hong i sur. (2014) su pokazali kako najviše poteškoća u učenju imaju učenici s dijagnozom ADHD-a, a odmah iza njih slijede učenici koji su suspektni na ADHD-a. Nadalje, istraživanja su pokazala da djeca s ADHD-om zaista procjenjuju mogući uspjeh na umjereno izazovnim zadacima mnogo niže nego kontrola grupa djece bez ADHD-a, pa čak i djeca s ADHD-om koja na početku zadataka procjenjuju visoku samoučinkovitost puno brže će odustati od završetka zadataka nego djeca iz kontrolne grupe (Dunn i Shapiro, 1999). Učenici s ADHD-om manje su uporni u akademskim zadacima, dijelom i zbog toga što su počeli vjerovati da oni nemaju ono što je potrebno za uspjeh (DuPaul i Langberg, 2015; Honos-Webb, 2010). Longitudinalna studija djevojčica s ADHD-om ustanovila je kako je glavni rizični čimbenik za razvoj slabe akademske samoučinkovitosti kombinacija hiperaktivnosti i nepažnje (Young, Heptinstall, Sonuga-Barke, Chadwick i Taylor, 2005). Učenici s predominantno nepažljivim tipom i kombiniranim tipom ADHD-a imaju najlošije rezultate kako na kognitivnim tako i na testovima postignuća, najlošiji školski uspjeh, češće su smješteni u specijalne ustanove, sporija im je brzina obrade informacije i imaju veće deficite u izvršnim funkcijama u usporedbi s učenicima koji imaju predominantno hiperaktivno-impulzivni tip poremećaja (DuPaul i Langberg, 2015; Todd i sur., 2002).

Djeca i adolescenti s ADHD-om imaju kontinuirane probleme u kvantiteti i kvaliteti vršnjačkih odnosa (Becker i sur., 2006; Coghill i sur., 2006), ne sklapaju prijateljstva (Meltzer, Gatward, Goodman i Ford, 2003), a ako i imaju prijatelje poprilično su ograničeni u svojim aktivnostima s njima (Escobar, Soutullo, Hervas, Gastaminza, Polavieja i Gilaberte, 2005). Također su i kod djece suspektne na ADHD zamijećeni problemi u odnosima s vršnjacima (Norén Selinus i sur., 2016). Iako vrlo lako i brzo upoznaju prijatelje, zbog specifičnosti poremećaja, posebice nemogućnosti slijeđenja pravila, negativnog, ometajućeg ponašanja i pomanjkanja 
socijalnih vještina (npr. u društvenim igrama i zajedničkim aktivnostima), ti odnosi kratko traju i često rezultiraju time da su djeca s ADHD-om vrlo brzo odbačena od novih prijatelja (McQuade i Hoza, 2015; Mrug i sur., 2009). Mikami i Normand (2015) ističu da je kod djece s ADHD-om kvaliteta odnosa s drugima snižena, tj. djeca s ADHD-om su nezadovoljna odnosima s drugima, češće od ostale djece se osjećaju odbačenima te posljedično pokazuju simptome depresije u usporedbi s djecom koja nemaju ADHD (Houck, Kendall, Miller, Morrell i Wiebe, 2012; McQuade i Hoza, 2015; Paap, Haraldsen, Breivik, Butcher, Hellem i Stormark, 2013). Istraživanje djece suspektne na ADHD je pokazalo kako imaju manji broj prijatelja, općenito im je kvaliteta prijateljstva lošija te češće imaju negativnu reputaciju među vršnjacima u usporedbi s kontrolnom skupinom djece koja ne pokazuju simptome ADHD-a (Rielly, Craig i Parker, 2006). Oko 70\% djece s ADHD-om nemaju bliskog prijatelja do 3. razreda osnovne škole, a posebice ako imaju komorbiditet s poremećajem ophođenja s prkošenjem. Ti problemi rezultat su nemogućnosti djeteta S ADHD-om da učinkovito sudjeluje u društvenim razmjenama, kao što su dijeljenje, suradnja i uzajamnost (Barkley, 2015). Osim hiperaktivnosti i simptomi impulzivnosti mogu značajno narušavati socijalno funkcioniranje, posebice jer su povezani s nasilnim i agresivnim ponašanjem prema vršnjacima (McQuade i Hoza, 2015). Corkum, Corbin i Pike (2010) smatraju da impulzivnost, kao jedan od vodećih simptoma ADHD-a, utječe na verbalne sposobnosti i komunikacijske vještine djece $i$ to na način da su skloni prekidanju tuđih razgovora, nepromišljenosti u razgovoru (nesmotrenosti) i neprepoznavanju tuđih emocija, što rezultira konfliktima u interakciji. Posljedično, vršnjaci djecu s ADHD-om isključuju te su oni u većem riziku od razvoja ovisnosti i psihičkih poremećaja (depresije) u odrasloj dobi (Barkley, 2015; Defoe i sur., 2013; Lachenmeier, 2014).

Problemi u socijalnim odnosima koje doživljaju djeca sADHD-om su djelomično posljedica i problema u emocionalnom funkcioniranju. Emocionalni deficiti djece i adolescenata s ADHD-om uključuju lošu samoregulaciju emocija, pretjerano burno emocionalno izražavanje, posebice ljutnje i agresije, veće probleme suočavanja s frustracijom, smanjenu empatiju te je smanjen stupanj uzbuđenja na stimulaciju (Barkley, 2015; Becker i sur., 2006; Meltzer i sur., 2003). Dječaci s ADHD-om i komorbiditetom s poremećajem ophođenja s prkošenjem imaju najviše problema sa slabom regulacijom negativnih emocija (Treuting i Hinshaw, 2001). Anksioznost i depresivnost također su uobičajeni u komorbiditetu s ADHD-om (Elia, Ambrosini i Berrettini, 2008; Steinhausen i sur., 2006), što naravno utječe na sposobnost regulacije i nošenja s negativnim emocijama (Lachenmeier, 2014; Wender, Wolf i Wasserstein, 2001). Druge studije naglašavaju emocionalne teškoće kao što su pomanjkanje pozitivnog raspoloženja i česte provale bijesa (Whalen, Jamner, Henker, Delfino i Lozano, 2002). Djeca s ADHD-om imaju problema u vršnjačkim odnosima prvenstveno zbog nemogućnosti prepoznavanja tuđih emocija i namjera te regulacije vlastitih emocija, zbog čega djeca s ADHD-om teško održavaju usmjerenost na vršnjake tijekom interakcije (Sjöwall i Thorell, 2014). Osim toga, koriste se manjim 
brojem strategija usmjerenih na rješavanje problema, a većim brojem strategija koje se temelje na emocijama, što predstavlja teškoću u regulaciji emocionalno nabijenih situacija, pogotovo kada je riječ o negativnim emocijama (Hampel, Manhal, Roos i Desman, 2008). Kao najveći problem u odnosima s vršnjacima Schwenck, Schmitt, Sievers, Romanos, Warnke i Schneider (2011) vide nisku razinu empatije koju obrazlažu nedostatkom informacija/uvida u emocionalna stanja druge djece $i$ to na način da se (zbog organske podloge) informacije o odnosima na mikro-razini ustrojavaju na specifičan način, što u kombinaciji s nepovoljnim utjecajima okoline rezultira nižom razinom osjetljivosti za druge. Jogsan (2013) je utvrdio kako djeca s ADHD-om pokazuju slabiju emocionalnu zrelost i prilagodbu u odnosima s drugima, odnosno probleme u kontroliranju svojih emocija ovisno o situaciji. U skladu s tim su i istraživanja emocionalne inteligencije koja kreću od pretpostavke da su poteškoće u obradi emocija i regulaciji afekata važne značajke ADHD-a, pa je tako i utvrđeno da je emocionalna inteligencija dobar prediktor oba tipa ADHDa, predominantno hiperaktivno-impulzivnog tipa i predominantno nepažljivog tipa poremećaja, pri čemu su se najznačajnijim prediktorima pokazale dimenzije upravljanja stresom i prilagodljivost (Kristensen, Parker, Taylor, Keefer, Kloosterman i Summerfeldt, 2014).

Iz pregleda relevantne literature vidljivo je kako djeca s dijagnozom ADHD-a pokazuju probleme u akademskoj, socijalnoj i emocionalnoj prilagodbi, za razliku od djece bez ADHD-a, a u nekim slučajevima i odnosu na djecu suspektnu na ADHD. Međutim, istraživanja koja su se bavila djecom suspektnom na ADHD nisu uvijek koristila kriterije prema DSM-5 dijagnostičkom priručniku pri određenju suspektnosti, već različite skale procjena, što je dovelo do neujednačenosti dobivenih rezultata malobrojnih istraživanja. Nadalje, istraživanje na nastavnicima osnovnih škola pokazalo je kako preko $90 \%$ nastavnika nije upoznato s kriterijima DSM-IV za dijagnosticiranje ADHD-a, ali su bez obzira na nepoznavanje problematike spremno procijenili koja su djeca suspektna na ADHD (Rafalovich, 2008), što predstavlja dodatni problem pri procjeni simptoma ADHD-a od strane učitelja. Pretpostavka je da i djeca suspektna na ADHD, a ne isključivo ona s dijagnozom, zbog postojanja pojedinih simptoma ADHD-a imaju problema na akademskom, socijalnom i emocionalnom planu, no za razliku od djece kojoj je ADHD dijagnosticiran, ova skupina ne prima nikakvu dodatnu podršku (npr. pomoćnika u nastavi ili individualizirani pristup) niti je uključena u prevencijske i intervencijske programe (Balázs i Keresztény, 2014), što bi svakako bilo potrebno.

Kako su se dosadašnja istraživanja uglavnom usmjerila na djecu koja već imaju potvrđenu dijagnozu ADHD-a, kao i čest komorbiditet s drugim poremećajima, u provedenom istraživanju željeli smo se usmjeriti na djecu koja su suspektna na ADHD, a pritom i visokorizična za razvoj socijalno neprihvatljivih ponašanja. Polazište za uključivanje dječje samoprocjene simptoma ADHD-a prema kriterijima DSM-5 bila su prethodna istraživanja koja su pokazala probleme u nastavničkim procjenama i različitim skalama procjena koje su se koristile (Balázs i Keresztény, 
2014; Rafalovich, 2008). Cilj je istraživanja provjeriti akademsko (školski uspjeh, akademska samoefikasnost), socijalno (broj prijatelja, vršnjačka prihvaćenost, socijalna samoefikasnost) i emocionalno (empatija, emocionalna kompetentnost, emocionalna samoefikasnost) funkcioniranje djece suspektne na ADHD, pri čemu pretpostavljamo da su ovi aspekti funkcioniranja narušeni u odnosu na vršnjake bez simptoma ADHD-a. Također smo željeli provjeriti postoje li razlike u akademskom, socijalnom i emocionalnom funkcioniranju djece s obzirom na tip samoprocijenjenog poremećaja (predominantno hiperaktivno-impulzivni, predominantno nepažljivi ili kombinirani tip). Pretpostavljamo da kod djece kod koje su više izraženi simptomi nepažnje, istovremeno će biti i više narušeno akademsko funkcioniranje, dok kod djece kod koje su više izraženi simptomi hiperaktivnosti i impulzivnosti više će biti narušeno socijalno i emocionalno funkcioniranje.

\section{METODA}

\section{Sudionici}

Istraživanje je obuhvatilo 6 osnovnih škola. Sudionici su bili učenici četvrtih, šestih i osmih razreda. Ukupan broj učenika koji su pitani za sudjelovanje je 896, a pristao je sudjelovati 501 (55,92\%), od čega su 492 sudionika dala potpune podatke. Samo je 7 učenika $(1,4 \%)$ koji su dobili roditeljski pristanak za sudjelovanje u istraživanju i koji su popunili upitnike imalo dijagnozu ADHD-a. Oni nisu pohađali školu prema prilagođenom, nego po individualiziranom programu, isto kao i 3 druga učenika zbog drugih teškoća. U Tablici 1 prikazana je raspodjela učenika po spolu, dobi i razredu koji pohađaju.

Tablica 1. Raspodjela učenika po spolu i razredu koji pohađaju

\begin{tabular}{llrrl}
\hline razred & spol & \multicolumn{1}{c}{$\mathrm{f}$} & \multicolumn{1}{c}{$\%$} & prosječna dob \\
\hline \multirow{3}{*}{ 4. razred } & dječaci & 50 & 48 & $\mathrm{M}=10,9$ \\
& djevojčice & 54 & 52 & $\mathrm{sd}=0,48$ \\
& ukupno & 104 & 20,8 & \\
\hline \multirow{3}{*}{ 6. razred } & dječaci & 91 & 49,2 & \multirow{2}{*}{$\mathrm{M}=12,25$} \\
& djevojčice & 94 & 50,8 & $\mathrm{sd}=0,46$ \\
& ukupno & 185 & 36,9 & \\
\multirow{3}{*}{ 8. razred } & dječaci & 112 & 52,6 & $\mathrm{M}=14,32$ \\
& djevojčice & 100 & 47,4 & $\mathrm{sd}=0,49$ \\
& ukupno & 212 & 42,3 & \\
\multirow{2}{*}{ ukupno } & dječaci & 254 & 50,7 & \multirow{2}{*}{$\mathrm{M}=12,72$} \\
& djevojčice & 247 & 49,3 & $\mathrm{sd}=1,62$ \\
& ukupno & 501 & 100,0 & \\
\hline
\end{tabular}


Instrumenti

\section{Skala hiperaktivnost-impulzivnost-pažnja (HIP; Vulić-Prtorić, 2006)}

Skala HIP procjenjuje hiperaktivno i impulzivno ponašanje, te poteškoće u usmjeravanju pažnje. Ukupno se sastoji od 19 čestica, a podijeljena je na tri subskale: hiperaktivnost ( 6 čestica), impulzivnost (4 čestice) i nepažnja (9 čestica). Čestice opisuju najčešće simptome hiperaktivnosti, impulzivnosti i nepažnje. Skala HIP konstruirana je na temelju popisa simptoma iz DSM-IV koji se koriste za mjerenje simptoma poremećaja deficita pažnje s hiperaktivnošću i za teorijsko tumačenje simptoma ADHD-a. Zadatak sudionika je procijeniti koliko često su im se određena ponašanje javljala tijekom posljednjih 6 mjeseci. U skladu s time, pored svake tvrdnje treba zaokružiti jedan broj: $1=$ nikada, $2=$ rijetko, $3=$ ponekad, $4=$ često, $5=$ vrlo često. Rezultat se dobiva aritmetičkom sredinom odabranih čestica. Pouzdanost za subskalu hiperaktivnosti iznosi Cronbach $\alpha=0,86$, za subskalu impulzivnosti $\alpha=0,80$ te za subskalu pažnje $\alpha=0,88$.Za potrebe ovog istraživanja dijete je stavljeno u kategoriju samoprocijenjene dijagnoze ADHD-a ako je na minimalno 6 ili više pitanja označilo da mu se određeno ponašanje javlja "često (4)" ili "vrlo često (5)", a u kategoriju suspektno na ADHD ako je na 4 ili 5 pitanja označilo da mu se određeno ponašanje javlja "često (4)" ili "vrlo često (5)". Ovo je ujedno i stroži kriterij prema kojemu se djeca svrstana u kategoriju suspektni na ADHD (Airaksinen, Michelsson i Jokela, 2004; Bussing i sur., 2010; Bussing, Porter, Zima, Mason, Garvan i Reid, 2012), posebice zato što je procjenu davalo samo dijete, a ne učitelji i roditelji. Dijete je identificirano kao suspektno na ADHD ako je samoprocijenilo za 4 ili 5 opisanih ponašanja (zaokružilo 4 ili 5 tvrdnji, tj. simptoma) da mu se događaju "često" (zaokružilo broj 4) ili "vrlo često" (zaokružilo broj 5), što je ujedno smatrano i blažim kriterijem za određenje suspektnih na ADHD (Biederman, Petty, Evans, Small i Faraone, 2010; Fergusson i sur. , 2010). Djeca su identificirana i prema tipovima ADHD-a prema kriterijima iz DSM-5 klasifikacije. Tvrdnjama u Upitniku HIP opisane su tri skupine simptoma: nepažnja (deficit pažnje), hiperaktivnost i impulzivnost. Ako je dijete samoprocijenilo za 6 ili više simptoma (zaokružilo 6 ili više tvrdnji) nepažnje, ali manje od 6 simptoma hiperaktivnostiimpulzivnosti da mu se događaju "često" ili "vrlo često", identificirano je da ima deficit pažnje/hiperaktivni poremećaj (ADHD) - predominantno nepažljivi tip. Ako je dijete samoprocijenilo za 4 ili 5 simptoma (zaokružilo 4 ili 5 tvrdnji) nepažnje, ali manje od 4 simptoma hiperaktivnosti - impulzivnosti da mu se događaju "često" ili "vrlo često"), identificirano je da je suspektno na predominantno nepažljivi tip ADHD-a. Na isti su način kategorizirani i ostali tipovi poremećaja (Tablica 2). Iako se ne radi o formalno potvrđenoj liječničkoj dijagnozi, u tekstu će se koristiti oznake "dijagnoza ADHD-a" (za skupinu djecu koja su prema strožem kriteriju suspektna na ADHD), "suspektni na ADHD" (za skupinu djece koja su prema blažem kriteriju suspektna na ADHD), "nema ADHD”, te "predominantno nepažljivi tip", 
Velki, T., Romstein, K., Akademsko, socijalno i emocionalno funkcioniranje djece suspektne na ADHD, Klinička psihologija 10 (2017), 1-2, 35-58

Tablica 2. Način kategorizacije djece u radu u odnosu na suspektni tip poremećaja

\begin{tabular}{lll}
\hline & \multicolumn{1}{c}{ Nepažnja } & \multicolumn{1}{c}{$\begin{array}{c}\text { Hiperaktivnost- } \\
\text { impulzivnost }\end{array}$} \\
\hline Predominantno nepažljivi tip & $\geq 6$ simptoma & $<6$ simptoma \\
Suspektno predominantno nepažljivi tip & 4 ili 5 simptoma & $<4$ simptoma \\
Predominantno hiperaktivno-impulzivni tip & $<6$ simptoma & $\geq 6$ simptoma \\
Suspektno predominantno hiperaktivno-impulzivni tip & $<4$ simptoma & 4 ili 5 simptoma \\
Kombinirani tip & $\geq 6$ simptoma & $\geq 6$ simptoma \\
Suspektno kombinirani tip & 4 ili 5 simptoma & 4 ili 5 simptoma \\
\hline
\end{tabular}

Napomena: simptomima se smatra ako dijete za česticu zaokruži odgovor 4 (često) ili 5 (vrlo često)

"predominantno hiperaktivno-impulzivni tip", "kombinirani tip", s obzirom na samoprocjenu simptoma za dijagnozu ADHD-a u upitniku HIP, a prema kriterijima DSM-5, radi lakšeg praćenja rezultata istraživanja i rasprave.

\section{Upitnik samoefikasnosti za djecu (SEQ-C, Vulić-Prtorić i Sorić, 2006)}

Upitnik samoefikasnosti za djecu ispituje dječji osjećaj samoefikasnosti u 3 različita područja: akademska samoefikasnost, socijalna samoefikasnost i emocionalna samoefikasnost. Upitnik se sastoji od 24 čestice podijeljene na 3 subskale: Skala akademske samoefikasnosti $(\mathrm{k}=8)$, koja se odnosi na percipiranu mogućnost snalaženja u učenju i školskom gradivu te na ispunjavanje školskih očekivanja; Skala socijalne samoefikasnosti $(\mathrm{k}=9)$, koja se odnosi na percipiranu sposobnost za odnose s vršnjacima te asertivnost; Skala emocionalne samoefikasnosti $(k=7)$, koja se odnosi na percipiranu sposobnost suočavanja s negativnim emocijama. Zadatak sudionika je procijeniti koliko se određeno opisano ponašanje odnosi na njih. U skladu s time, pored svake tvrdnje treba zaokružiti jedan broj: 1 - uopće NE, 2 - uglavnom NE, 3 - nisam siguran, 4 - uglavnom DA, 5 - u potpunosti DA. Rezultat se dobiva aritmetičkom sredinom odabranih čestica. Pouzdanost u našem istraživanju za subskalu akademska samoefikasnost iznosi Cronbach $\alpha=0,84$, za subskalu socijalna samoefikasnost $\alpha=0,80$ te za subskalu emocionalna samoefikasnost $\alpha=0,79$.

\section{Upitnik emocionalne kompetentnosti (UEK-45; Takšić, 2002)}

UEK-45 je skraćena verzija Upitnika emocionalne inteligencije UEK-136 konstruiranog po modelu Mayera i Saloveya (1997). Sastoji se od tri subskale koje procjenjuju sposobnost uočavanja i razumijevanja emocija $(\mathrm{k}=15)$, sposobnost izražavanja i imenovanja emocija $(\mathrm{k}=14)$ te sposobnost upravljanja emocijama $(\mathrm{k}$ =16). Zadatak sudionika je procijeniti koliko se ponuđene tvrdnje odnose na njih same tako što će zaokružiti broj na skali od 5 stupnjeva, pri čemu broj 1 označava 
- uopće NE, 2 - uglavnom NE, 3 - kako kada, 4 - uglavnom DA i 5 - u potpunosti DA. Rezultat se dobiva aritmetičkom sredinom odabranih čestica subskale. Također se može formirati i ukupan rezultat kao mjera opće emocionalne kompetentnosti, što je i napravljeno u provedenom istraživanju te je dobivena pouzdanost za opće emocionalnu kompetentnost iznosila Cronbach $\alpha=0,92$.

\section{E-upitnik: skala emocionalne empatije (Raboteg-Šarić, 2002)}

E-upitnik se sastoji od dvije skale: Skala emocionalne empatije i Skala mašte. Skala emocionalne empatije mjeri opću afektivnu empatiju koja se javlja prilikom percipiranja emocionalnog iskustva drugih ljudi te sadrži 19 tvrdnji koje opisuju emocionalne doživljaje sukladne čuvstvenom stanju drugih te osjećaje simpatije prema onima koji su u nevolji. Skala mašte mjeri tendenciju uživljavanja u maštu, osjećaje i aktivnosti zamišljenih likova iz priča, romana i filmova i sl. $(\mathrm{k}=6)$. Za potrebe provedenog istraživanja primijenjena je samo Skala emocionalne empatije. Zadatak sudionika je procijeniti koliko ga navedena tvrdnja dobro opisuje, pri čemu brojevi znače sljedeće: 1 - uopće se ne odnosi na mene, 2 - uglavnom se ne odnosi na mene, 3 - niti se odnosi, niti se ne odnosi na mene, 4 - uglavnom se odnosi na mene i 5 - u potpunosti se odnosi na mene. Rezultat se dobiva aritmetičkom sredinom čestica, a $\mathrm{u}$ provedenom istraživanju dobivena je pouzdanost Cronbach $\alpha=0,92$.

\section{Opći podaci}

$\mathrm{Na}$ početku istraživanja učenici su popunili anketu o demografskim podacima (spol, dob, mjesto stanovanja, s kim žive), a u sklopu toga su dali i podatke o školskom uspjehu. Kako bismo dobili precizniju mjeru učenikova uspjeha, izračunali smo kompozitnu mjeru općeg uspjeha na kraju polugodišta i na kraju prošle školske godine, ocjene iz matematike na polugodištu i na kraju prošle školske godine, ocjene iz hrvatskog jezika na polugodištu i na kraju prošle školske godine (čija je pouzdanost u provedenom istraživanju iznosila Cronbach $\alpha=0,79$ ). Dali su još podatke o broju (najboljih) prijatelja. Za varijablu broj prijatelja učenici su sami pisali broj najboljih prijatelja, koji je naknadno kategoriziran u 5 kategorija (0 znači nema prijatelja, 1 označava da ima 1-3 prijatelja, 2 označava da ima 4-6 prijatelja, 3 označava da ima 7-9 prijatelja i 4 označava da ima više od 10 prijatelja). Također su dali podatak i o osjećaju vršnjačke prihvaćenosti, gdje su trebali procijeniti na dvije čestice koliko se osjećaju prihvaćeno/odbačeno od strane vršnjaka (1-nikad, 2-ponekad, 3-često), a pouzdanost u provedenom istraživanju iznosila je Cronbach $\alpha=0,68$.

\section{Postupak}

Nakon dogovora sa školama i dobivenog odobrenja za primjenu upitnika, prikupljene su suglasnosti roditelja. Samo istraživanje provedeno je grupno, u sklopu 
sata razrednika, a ukupna primjena trajala je oko 45 minuta. Naglašeno je da je ispitivanje anonimno te da nema točnih i netočnih odgovora, već je važna iskrenost pri ispunjavanju upitnika. Na početku svakog upitnika učenicima je dana detaljna uputa, a ako je tijekom ispunjavanja upitnika nešto bilo nejasno, istraživačica je pojedinačno svakome pojasnila. S učenicima koji su nastavu pohađali prema individualiziranom pristupu $(\mathrm{N}=10)$, za vrijeme popunjavanja upitnika bili su njihovi pomoćnici u nastavi koji su im pomagali. Sudionici su u bilo kojem trenutku mogli odustati, ali nije bilo takvih slučajeva.

\section{REZULTATI}

Varijable prikazane u Tablici 3 dobivene su na temelju aritmetičkih sredina čestica Skale hiperaktivnosti-impulzivnosti-pažnje (HIP), kao i skala i subskala Upitnika samoefikasnosti za djecu (SEQ-C), Upitnika emocionalne kompetencije (UEK-45) i Skale emocionalne empatije.

Za samoprocjenu dijagnoze ADHD-a i podjelu učenika prema tipovima ADHDa koristili smo Upitnik HIP (Skala hiperaktivnost-impulzivnost-pažnja), a rezultati su prikazani u Tablici 4. Upitnik HIP konstruiran je na temelju simptoma iz DSMIV klasifikacije, a isti su zadržani u DSM-5 klasifikaciji. Za identifikaciju dijagnoze ADHD-a prema samoprocjeni koristili smo kriterije iz DSM-5 klasifikacije.

S obzirom na samoprocjenu imaju li simptome određenog tipa ADHD-a ili ne, tablica 4 prikazuje broj djece koja nemaju ADHD i broj djece prema tipovima ADHD-a. Grupe "suspektni na ADHD” i "dijagnoza ADHD-a" u tablici su prika-

Tablica 3. Prikaz deskriptivnih podataka za mjerene varijable

\begin{tabular}{lccccc}
\hline VARIJABLA & $N$ & Min & Max & $M$ & $S D$ \\
\hline hiperaktivnost & 501 & 1,00 & 5,00 & 2,28 & 1,02 \\
impulzivnost & 500 & 1,00 & 5,00 & 2,15 & 0,95 \\
nepažnja & 500 & 1,00 & 4,78 & 2,14 & 0,89 \\
\hline emocionalna empatija & 501 & 1,00 & 5,00 & 3,76 & 0,79 \\
emocionalna kompetentnost & 501 & 1,76 & 5,00 & 3,74 & 0,54 \\
emocionalna samoefikasnost & 501 & 1,00 & 5,00 & 3,38 & 0,83 \\
\hline školski uspjeh & 501 & 1,67 & 5,00 & 4,09 & 0,80 \\
akademska samoefikasnost & 501 & 1,00 & 5,00 & 3,57 & 0,83 \\
\hline broj prijatelja & 501 & 0,00 & 4,00 & - & - \\
vršnjačka prihvaćenost & 501 & 1,00 & 3,00 & 2,62 & 0,50 \\
socijalna samoefikasnost & 501 & 1,00 & 5,00 & 3,74 & 0,74 \\
\hline
\end{tabular}


Velki, T., Romstein, K., Akademsko, socijalno i emocionalno funkcioniranje djece suspektne na ADHD, Klinička psihologija 10 (2017), 1-2, 35-58

Tablica 4. Broj djece s obzirom na samoprocijenjenu dijagnozu i prema tipovima ADHD-a

\begin{tabular}{|c|c|c|c|c|c|}
\hline Samoprocjena ADHD-a & f & $\%$ & $\begin{array}{l}\text { suspektni na ADHD i } \\
\text { dijagnoza ADHD-a (zajedno) }\end{array}$ & $\mathrm{f}$ & $\%$ \\
\hline nema ADHD & 371 & 75,4 & predominantno nepažljivi tip & 19 & 3,9 \\
\hline suspektni na ADHD & 55 & 11,2 & $\begin{array}{l}\text { predominantno hiperaktivno- } \\
\text { impulzivni tip }\end{array}$ & 55 & 11,2 \\
\hline dijagnoza ADHD-a & 66 & 13,4 & kombinirani tip & 47 & 9,5 \\
\hline ukupno & 492 & 100,0 & ukupno & 123 & 24,6 \\
\hline
\end{tabular}

zane zajedno i podijeljene su na još 3 grupe, tj. tipove ADHD-a: "predominantno nepažljivi tip", "predominantno hiperaktivno-impulzivni tip", "kombinirani tip". Kod podjele na tipove ADHD poremećaja odlučili smo spojiti kategorije "dijagnoza" i "suspektni" zbog malog broja djece koja bi prema ovoj podjeli pripadala u određenu kategoriju.

Jednosmjernom analizom varijance provjerene su razlike u akademskom, socijalnom i emocionalnom funkcioniranju djece s obzirom na to procjenjuje li dijete da ima dovoljno simptoma za dijagnozu ADHD-a, samo je suspektno na ADHD ili nema simptome poremećaja.

Post hoc analiza uz Games-Howellovu korekciju pokazala je da postoji statistički značajna razlika za sva tri aspekta funkcioniranja djece (akademsko, socijalno i emocionalno) između sudionika koji prema samoprocjeni imaju ADHD, koji su prema samoprocjeni suspektni na ADHD i sudionika koji prema samoprocjeni nemaju ADHD. Mala veličina efekta pronađena je za školski uspjeh, vršnjačku prihvaćenost i emocionalnu samoefikasnost, dok je za akademsku samoefikasnost pronađena umjerena veličina efekta. Djeca koja prema samoprocjeni nemaju ADHD pokazuju statistički značajno bolji školski uspjeh i bolju emocionalnu samoefikasnost u odnosu na djecu koja prema samoprocjeni imaju dijagnozu ADHD-a, ali se ne razlikuju od djece suspektne na ADHD. Također, djeca koja prema samoprocjeni nemaju ADHD pokazuju statistički značajno bolju akademsku samoefikasnost i veću vršnjačku prihvaćenost za razliku od djece koja prema samoprocjeni imaju dijagnozu ADHD-a, ali i koja samoprocjenjuju da su suspektna na ADHD.

Također smo analizom varijance provjerili razlikuju li se sudionici s različitim samoprocijenjenim tipovima ADHD-a (predominantno nepažljivi, predominantno hiperaktivno-impulzivni ili kombinirani tip) u akademskom, socijalnom i emocionalnom funkcioniranju.

Post hoc analizom uz Games-Howellovu korekciju utvrđene su razlike u akademskom, socijalnom i emocionalnom funkcioniranje djece za različite tipove ADHD-a. Veličina efekta za dobivene razlike je mala (školski uspjeh, vršnjačka prihvaćenost, socijalna samoefikasnost, emocionalna kompetentnost, emocionalna samoefikasnost) do umjerena (akademska samoefikasnost). Slabiji školski uspjeh 
Velki, T., Romstein, K., Akademsko, socijalno i emocionalno funkcioniranje djece suspektne na ADHD, Klinička psihologija 10 (2017), 1-2, 35-58

Tablica 5. Razlike u akademskom, socijalnom i emocionalnom funkcioniranju s obzirom na samoprocjenu simptoma ADHD-a

\begin{tabular}{|c|c|c|c|c|c|c|c|}
\hline \multicolumn{2}{|c|}{ Funkcioniranje djece } & ADHD & $N$ & $M$ & $S D$ & $F$ & $\omega$ \\
\hline \multirow{8}{*}{ 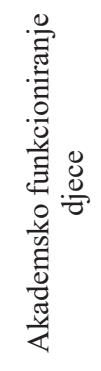 } & \multirow{4}{*}{ školski uspjeh } & nema ADHD & 371 & 4,15 & 0,80 & \multirow{4}{*}{$3,89 *$} & \multirow{4}{*}{0,11} \\
\hline & & suspektni na ADHD & 55 & 3,95 & 0,80 & & \\
\hline & & dijagnoza ADHD & 66 & 3,89 & 0,76 & & \\
\hline & & ukupno & 492 & 4,09 & 0,80 & & \\
\hline & \multirow{4}{*}{$\begin{array}{l}\text { akademska } \\
\text { samoefikasnost }\end{array}$} & nema ADHD & 371 & 3,71 & 0,78 & \multirow{4}{*}{$23,46 * *$} & \multirow{4}{*}{0,29} \\
\hline & & suspektni na ADHD & 55 & 3,33 & 0,79 & & \\
\hline & & dijagnoza ADHD & 66 & 3,03 & 0,88 & & \\
\hline & & ukupno & 492 & 3,57 & 0,83 & & \\
\hline \multirow{12}{*}{ 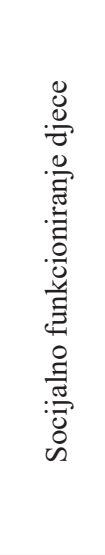 } & \multirow{4}{*}{ broj prijatelja } & nema ADHD & 371 & 1,77 & 1,05 & \multirow{4}{*}{1,20} & \\
\hline & & suspektni na ADHD & 55 & 1,62 & 1,00 & & \\
\hline & & dijagnoza ADHD & 66 & 1,92 & 1,19 & & \\
\hline & & ukupno & 492 & 1,77 & 1,06 & & \\
\hline & \multirow{4}{*}{$\begin{array}{l}\text { vršnjačka } \\
\text { prihvaćenost }\end{array}$} & nema ADHD & 371 & 2,66 & 0,47 & \multirow{4}{*}{$4,35^{*}$} & \multirow{4}{*}{0,12} \\
\hline & & suspektni na ADHD & 55 & 2,49 & 0,55 & & \\
\hline & & dijagnoza ADHD & 66 & 2,51 & 0,57 & & \\
\hline & & ukupno & 492 & 2,62 & 0,50 & & \\
\hline & \multirow{4}{*}{$\begin{array}{l}\text { socijalna } \\
\text { samoefikasnost }\end{array}$} & nema ADHD & 371 & 3,78 & 0,71 & \multirow{4}{*}{2,42} & \\
\hline & & suspektni na ADHD & 55 & 3,58 & 0,84 & & \\
\hline & & dijagnoza ADHD & 66 & 3,65 & 0,76 & & \\
\hline & & ukupno & 492 & 3,74 & 0,73 & & \\
\hline \multirow{12}{*}{ 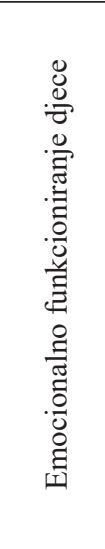 } & \multirow{4}{*}{$\begin{array}{l}\text { emocionalna } \\
\text { empatija }\end{array}$} & nema ADHD & 371 & 3,79 & 0,78 & \multirow{4}{*}{1,12} & \\
\hline & & suspektni na ADHD & 55 & 3,72 & 0,72 & & \\
\hline & & dijagnoza ADHD & 66 & 3,63 & 0,90 & & \\
\hline & & ukupno & 492 & 3,76 & 0,79 & & \\
\hline & \multirow{4}{*}{$\begin{array}{l}\text { emocionalna } \\
\text { kompetentnost }\end{array}$} & nema ADHD & 371 & 3,77 & 0,51 & \multirow{4}{*}{2,63} & \\
\hline & & suspektni na ADHD & 55 & 3,65 & 0,65 & & \\
\hline & & dijagnoza ADHD & 66 & 3,64 & 0,58 & & \\
\hline & & ukupno & 492 & 3,74 & 0,54 & & \\
\hline & \multirow{4}{*}{$\begin{array}{l}\text { emocionalna } \\
\text { samoefikasnost }\end{array}$} & nema ADHD & 371 & 3,46 & 0,80 & \multirow{4}{*}{$6,76^{* *}$} & \multirow{4}{*}{0,15} \\
\hline & & suspektni na ADHD & 55 & 3,24 & 0,98 & & \\
\hline & & dijagnoza ADHD & 66 & 3,09 & 0,80 & & \\
\hline & & ukupno & 492 & 3,39 & 0,83 & & \\
\hline
\end{tabular}

${ }^{* *} \mathrm{p}<0,01 ;{ }^{*} \mathrm{p}<0,05$ 
Velki, T., Romstein, K., Akademsko, socijalno i emocionalno funkcioniranje djece suspektne na ADHD, Klinička psihologija 10 (2017), 1-2, 35-58

Tablica 6. Razlike u odnosu na samoprocijenjene grupe simptoma ADHD-a i akademsko, socijalno i emocionalno funkcioniranje djece

\begin{tabular}{|c|c|c|c|c|c|c|c|}
\hline \multicolumn{2}{|c|}{ Funkcioniranje djece } & ADHD & $N$ & $M$ & $S D$ & $F$ & $\omega$ \\
\hline \multirow{10}{*}{ 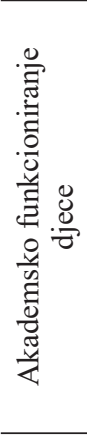 } & \multirow{5}{*}{ školski uspjeh } & nema ADHD & 371 & 4,15 & 0,80 & $2,62 *$ & 0,09 \\
\hline & & nepažljivi tip & 19 & 3,85 & 0,89 & & \\
\hline & & hiperaktivno-impulzivni tip & 55 & 3,95 & 0,78 & & \\
\hline & & kombinirani tip & 47 & 3,91 & 0,74 & & \\
\hline & & ukupno & 492 & 4,09 & 0,80 & & \\
\hline & \multirow{5}{*}{$\begin{array}{l}\text { akademska } \\
\text { samoefikasnost }\end{array}$} & nema ADHD & 371 & 3,71 & 0,78 & $14,64 * *$ & 0,28 \\
\hline & & nepažljivi tip & 19 & 2,99 & 0,78 & & \\
\hline & & hiperaktivno-impulzivni tip & 55 & 3,24 & 0,89 & & \\
\hline & & kombinirani tip & 47 & 3,14 & 0,83 & & \\
\hline & & ukupno & 492 & 3,58 & 0,83 & & \\
\hline \multirow{15}{*}{ 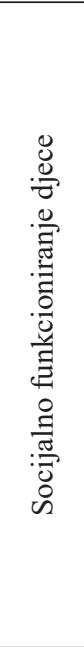 } & \multirow{5}{*}{ broj prijatelja } & nema ADHD & 371 & 1,77 & 1,05 & 0,18 & \\
\hline & & nepažljivi tip & 19 & 1,67 & 1,08 & & \\
\hline & & hiperaktivno-impulzivni tip & 55 & 1,77 & 1,11 & & \\
\hline & & kombinirani tip & 47 & 1,87 & 1,16 & & \\
\hline & & ukupno & 492 & 1,77 & 1,06 & & \\
\hline & \multirow{5}{*}{$\begin{array}{l}\text { vršnjačka } \\
\text { prihvaćenost }\end{array}$} & nema ADHD & 371 & 2,65 & 0,47 & $4,74 * *$ & 0,15 \\
\hline & & nepažljivi tip & 19 & 2,28 & 0,67 & & \\
\hline & & hiperaktivno-impulzivni tip & 55 & 2,59 & 0,51 & & \\
\hline & & kombinirani tip & 47 & 2,49 & 0,57 & & \\
\hline & & ukupno & 492 & 2,62 & 0,50 & & \\
\hline & \multirow{5}{*}{$\begin{array}{l}\text { socijalna } \\
\text { samoefikasnost }\end{array}$} & nema ADHD & 371 & 3,78 & 0,71 & $3,36^{*}$ & 0,12 \\
\hline & & nepažljivi tip & 19 & 3,31 & 0,89 & & \\
\hline & & hiperaktivno-impulzivni tip & 55 & 3,76 & 0,69 & & \\
\hline & & kombinirani tip & 47 & 3,57 & 0,84 & & \\
\hline & & ukupno & 492 & 3,74 & 0,73 & & \\
\hline \multirow{15}{*}{ 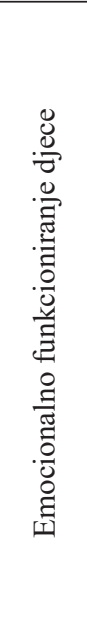 } & \multirow{5}{*}{$\begin{array}{l}\text { emocionalna } \\
\text { empatija }\end{array}$} & nema ADHD & 371 & 3,79 & 0,78 & 1,45 & \\
\hline & & nepažljivi tip & 19 & 3,49 & 0,73 & & \\
\hline & & hiperaktivno-impulzivni tip & 55 & 3,63 & 0,87 & & \\
\hline & & kombinirani tip & 47 & 3,80 & 0,78 & & \\
\hline & & ukupno & 492 & 3,76 & 0,79 & & \\
\hline & \multirow{5}{*}{$\begin{array}{l}\text { emocionalna } \\
\text { kompetentnost }\end{array}$} & nema ADHD & 371 & 3,77 & 0,51 & $3,98 * *$ & 0,13 \\
\hline & & nepažljivi tip & 19 & 3,39 & 0,65 & & \\
\hline & & hiperaktivno-impulzivni tip & 55 & 3,75 & 0,59 & & \\
\hline & & kombinirani tip & 47 & 3,63 & 0,60 & & \\
\hline & & ukupno & 492 & 3,75 & 0,54 & & \\
\hline & \multirow{5}{*}{$\begin{array}{l}\text { emocionalna } \\
\text { samoefikasnost }\end{array}$} & nema ADHD & 371 & 3,46 & 0,80 & $4,34 * *$ & 0,14 \\
\hline & & nepažljivi tip & 19 & 3,04 & 0,93 & & \\
\hline & & hiperaktivno-impulzivni tip & 55 & 3,15 & 0,78 & & \\
\hline & & kombinirani tip & 47 & 3,21 & 0,99 & & \\
\hline & & ukupno & 492 & 3,39 & 0,83 & & \\
\hline
\end{tabular}

${ }^{* *} \mathrm{p}<0,01 ;{ }^{*} \mathrm{p}<0,05$ 
pokazuju djeca sa samoprocijenjenim simptomima kombiniranog tipa u odnosu na djecu koju procjenjuju da nemaju simptome ADHD-a. Također učenici koji procjenjuju da nemaju simptome ADHD-a pokazuju bolju akademsku samoefikasnost od učenika koji procjenjuju da imaju simptome ADHD-a bilo koja od tri tipa (predominantno nepažljivi, predominantno hiperaktivno-impulzivni i kombinirani tip). Lošiju vršnjačku prihvaćenost i slabiju socijalnu samoefikasnost pokazuju učenici sa samoprocijenjenim simptomima predominantno nepažljivog tipa za razliku od učenika koji procjenjuju da nemaju simptome ADHD-a. Najslabije razvijenu emocionalnu kompetentnost imaju djeca sa samoprocijenjenim simptomima predominantno nepažljivog tipa i to u odnosu na djecu koja procjenjuju da nemaju ADHD i koja procjenjuju da imaju predominantno hiperaktivno-impulzivni, dok učenici sa samoprocijenjenim simptomima predominantno hiperaktivno-impulzivnog tipa procjenjuju slabije razvijenu emocionalnu kompetentnost za razliku samo od učenika koji procjenjuju da nemaju simptome ADHD-a.

\section{RASPRAVA}

Provedenim istraživanjem prvo se utvrdila prevalencija djece suspektne na ADHD. Rezultati samoprocijenjene dijagnoze ADHD-a (13,6\%) u skladu su s rezultatima u svijetu koji pokazuju kako se prevalencija ADHD-a kreće od najmanje 1 do skoro $20 \%$ kod djece školske dobi, što naravno ovisi o kriterijima koje pojedini istraživači koriste kada vrše procjenu simptoma (Faraone, Sergeant, Gillberg i Biederman, 2003; Polanczyk, de Lima, Horta, Biederman i Rohde, 2007), dok je kod nas prevalencija od 1 do 7\% (Kocijan-Hercigonja, 2008). Pregled istraživanja koja su se bavila djecom suspektnom na ADHD pokazuje kako se njihova prevalencija kreće od 0,8 do 23,1\%, ovisno o korištenoj metodologiji (Balázs i Keresztény, 2014), što je usporedivo s dobivenim rezultatima od $24,6 \%$ djece suspektne na ADHD (grupa suspektni i grupa samoprocjena dijagnoze) odnosno 13,6\% djece prema strožem kriteriju (grupa samoprocjena dijagnoze).

U odnosu na prvi cilj istraživanja dobivene su očekivane statistički značajne razlike u svim aspektima funkcioniranja djece (akademsko, socijalno i emocionalno funkcioniranje) suspektne na ADHD u odnosu na djeca koja procjenjuju da nemaju simptome ADHD-a, gdje su kod djece suspektne na ADHD narušeni svi opisani aspekti funkcioniranja. Dobiveni rezultati su očekivani i u skladu s prijašnjim istraživanjima provedenim na djeci i studenatima s dijagnozom ADHD-a (DuPaul i Langberg, 2015; Frazier i sur., 2007; Weyandt i DuPaul, 2008; Wu i Gau, 2013), ali i istraživanjima djece i adolescenta suspektnih na ADHD (August i sur.-, 1992; Bussing i sur., 2010; Norén Selinus i sur., 2016). Simptomi ADHD-a višestruko utječu na školski uspjeh, pri čemu djeca s dijagnozom ADHD-a pokazuje poteškoće s pamćenjem, izvršnim funkcijama, samoregulacijom i koncentracijom (Turnbull i sur., 2010), što uvelike ometa školski rad. Učenici suspektni na ADHD također pokazuju značajna odstupanja na testovima izvršnih funkcija (Hong i sur., 2014) i 
u školskom uspjehu (Bussing i sur., 2010), iako su ona blaža u usporedbi s djecom koja imaju dijagnosticiran poremećaj. Iz dobivenih rezultata vidljivo je da je slabiji školski uspjeh zamijećen samo kod učenika koji samoprocjenjuju jače izražene simptome ADHD-a (samoprocjenjuju da imaju simptome za dijagnozu ADHD-a) te da nema razlika između učenika koji su samoprocijenili da su suspektni na razvoj ADHD-a i onih koji su procijenili da nemaju ADHD. Moguće je da su djeca s blažim simptomima ADHD-a razvila određene strategije učenja te im ono ne predstavlja veći problem u obliku školskog uspjeha, odnosno ocjena. Međutim, procjena akademske samoefikasnosti statistički je značajno niža za obje rizične skupine (samoprocijenjena dijagnoza ADHD-a i suspektni na razvoj ADHD-a) u odnosu na djecu koja procjenjuju da nemaju simptome ADHD-a. Također je dobivena i umjerena veličina efekta, što nam govori u prilog tome da djeca suspektna na ADHD pokazuju slabiju akademsku samoučinkovitost. Dobiveni su rezultati u skladu s prijašnjim istraživanjima na djeci i studentima s dijagnozom ADHD-a (Dunn i Shapiro, 1999; Frazier i sur., 2007; Gropper i Tannock, 2009; Owens, Hinshaw, Lee i Lahey, 2009; Zajacova, Lynch i Espenshade, 2005), iako dosad nisu rađena istraživanja sa suspektnima na ADHD. Dakle čak i djeca koja nemaju formalno utvrđeno postojanje ADHD-a, ali pokazuju simptome poremećaja, imaju značajnih problemima s percepcijom akademske samoefikasnosti, gdje sebe doživljavaju kao manje kompetentnima u školskom području te su sklonija odustajanju kod težih zadataka i ulaganju manje truda (Velki, 2012), a posljedično ovakav obrazac ponašanja može voditi u naučenu bespomoćnost. Bespomoćnost, uz osobnu percepciju manje kompetentnosti u akademskom funkcioniranju, može imati dugoročne posljedice $\mathrm{u}$ smislu odustajanja od formalnog obrazovanja, što u odrasloj dobi vodi u nepovoljne socio-emocionalne uvjete življenja.

Iz rezultata je vidljivo da se za socijalno funkcioniranje djece suspektne na ADHD i one s ADHD-om pokazala značajna samo jedna varijabla. Djeca koja prema samoprocjeni nemaju ADHD procjenjuju statistički značajno veću vršnjačku prihvaćenost u odnosu na obje skupine suspektnih. Istraživanja su jasno pokazala kako djeca s ADHD-om, ali i ona suspektna na ADHD pokazuju kontinuirane problem u vršnjačkim odnosima (Becker i sur., 2006; Coghill i sur., 2006; Norén Selinus i sur., 2016), pri čemu se jasno ističe problem vršnjačke neprihvaćenosti ove skupine djece (McQuade i Hoza, 2015; Mrug i sur., 2009), odnosno negativne reputacije kod suspektnih na ADHD (Rielly i sur., 2006). Zbog specifičnosti simptoma ADHD-a ova djeca imaju problema u slijeđenju pravila i dogovora u igrama s vršnjacima, često prekidaju drugu djecu i impulzivno im ulijeću u igru, teško im je pratiti razgovor, što vodi tome da se jednostavno "ne uklapaju" u vršnjačke skupine te ih druga djeco nerado biraju u vlastite skupine za igru, druženje i aktivnosti. Posljedično, zbog kontinuiranog doživljavanja neuspjeha u odnosima s vršnjacima ova djeca mogu razviti i druge oblike neprikladnog ponašanja, najčešće nasilno i agresivno (McQuade i Hoza, 2015) kako bi došla do cilja, odnosno bila prihvaćena u vršnjačkim skupinama. 
$\mathrm{Za}$ emocionalno funkcioniranje djece suspektne na razvoj ADHD dobivene su najmanje razlike, također na jednoj varijabli. Djeca koja prema samoprocjeni nemaju ADHD pokazuju statistički značajno bolju emocionalnu samoefikasnost za razliku od djece koja prema samoprocjeni imaju dijagnozu ADHD-a (stroži kriterij suspektnosti). Za uspostavljanje i održavanje prikladnih vršnjačkih odnosa, ali i ostale socijalne odnose u djetetovoj okolini, bitna je i djetetova emocionalna zrelost, a istraživanja su pokazala da je kod djece s ADHD-om sniženo (Jogsan, 2013). Upravo ova nezrelost onemogućuje djetetu s ADHD-om da upravlja svojim emocijama ovisno o situaciji i ponaša se primjereno kontekstu u kojemu se nalazi, što posljedično dovodi do percepcije slabije emocionalne samoučinkovitosti, odnosno do lošijih međuljudskih odnosa. Za razliku od svojih vršnjaka, djeca s ADHD-om koriste se manjim brojem strategija usmjerenih na rješavanje problema, a većim brojem strategija koje se temelje na emocijama, što predstavlja teškoću u regulaciji emocionalno nabijenih situacija, pogotovo kada je riječ o negativnim emocijama (Hampel i sur., 2008). Za varijable emocionalna empatija i emocionalna kompetentnosti nismo utvrdili statiistčki značajne razlike, što je mogući odraz metodoloških nedostataka provedenog istraživanja (manji odaziv sudionika, istraživanje provedeno s djecom koja su suspektna na ADHD-a, a ne koja već imaju dijagnozu), kao i u djetetovu shvaćanju vlastitih postupaka, gdje zapravo djeca s ADHD-om (posebice predominantno hiperaktivno-impulzivnim tipom) nisu svjesna štetnosti svojih postupaka pa tako i ove aspekte emocionalnog funkcioniranja ne procjenjuje bitno drugačije od svojih vršnjaka.

U skladu s drugim ciljem istraživanja potvrdili smo razlike u akademskom, socijalnom i emocionalnom funkcioniranju djece s obzirom na samoprocjenu različitih tipova ADHD-a. Slabiji školski uspjeh se pokazao značajnim samo za učenike rizične za razvoj kombiniranog tipa ADHD-a, dakle gdje su podjednako izraženi svi simptomi ADHD-a. Iako su neka prijašnja istraživanja uglavnom govorila u prilog dominantnim problemima s nepažnjom kao jakim prediktorom prosjeka ocjena (Weyandt i DuPaul, 2008), dodatna istraživanja su pokazala da i simptomi hiperaktivnosti ometaju učenički rad i utječu na slabije školsko postignuće (Frazier i sur., 2007), odnosno da učenici s predominantno nepažljivim tipom i kombiniranim tipom ADHD-a imaju najlošiji školski uspjeh te veće deficite u izvršnim funkcijama (DuPaul i Langberg, 2015; Todd i sur., 2002). Nemogućnost koncentracije svakako ometa rad učenika, posebice kod težih i dugotrajnih zadataka, no također impulzivnost i hiperaktivnost, gdje učenik brzopleto rješava zadatke često s puno pogrešaka, šeta za vrijeme sata i ometa druge, značajno utječu na slabiji školski uspjeh, odnosno lošije ocjene. Kod njih je sporija i brzina obrade informacija pa im je često potrebno i duže vrijeme rješavanja zadatka. Nadalje za sva tri tipa ADHDa je potvrđeno da imaju slabiju akademsku samoefikasnost (pri čemu je dobivena umjerena veličina efekta), što opet govori u prilog tome da su zapravo svi simptomi ADHD-a ometajući i osim na uspjeh djeluju na učenikovu percepciju sebe kao manje kompetentnog učenika. Nažalost, to posljedično dovodi do sniženog samo- 
pouzdanja u svoje sposobnosti i donošenje budućih odluka (Norwalk, Norvilitis, i MacLean, 2009; Norvilitis, Sun i Zhang, 2010), pri čemu su ovi učenici skloniji odustajanju od daljnjeg školovanja (Pagani i sur., 2008).

Također se vide odstupanja i u socijalnom funkcioniranje, gdje učenici koji procjenjuju da imaju simptome predominantno nepažljivog tipa ADHD-a pokazuju slabiju socijalnu samoefikasnost i lošiju vršnjačku prihvaćenost za razliku od učenika koji procjenjuju da nemaju simptome ADHD-a. Očito je da simptomi nepažnje igraju značajnu ulogu u vršnjačkim odnosima. Nesposobnost praćenja razgovara, slijeđenja grupnih pravila i aktivnosti kao odraz simptoma nepažnje svakako negativno utječe na prihvaćenost unutar vršnjačke skupine, ali i na vlastiti osjećaj kompetencije, odnosno sposobnosti uspostavljanja i zadržavanja prijateljskih odnosa, iako ovo istraživanje nije pokazalo razlike s obzirom na broj prijatelja. Djeca suspektne na ADHD općenito imaju manji broj te procjenjuju kvalitetu prijateljstva lošijom u usporedbi s djecom koja ne pokazuju simptome ADHD-a (Rielly i sur., 2006). Istraživanja pokazuju ako djeca s ADHD-om i uspiju uspostaviti prijateljske odnose s vršnjacima, oni su poprilično ograničeni u svojim aktivnostima s njima (Escobar i sur., 2005), tj. ne posjeduju spektar različitih vještina koje bi vršnjacima bile zanimljive i zbog kojih bi željeli održati prijateljstvo. Nadalje, dodatni problem stvara i način na koji oni percipiraju svoje odnose s vršnjacima, pri čemu se često čini kao da nisu svjesna vlastitog negativnog socijalnog statusa (Diener i Milich, 1997), a kod suspektnih na ADHD utvrđeno je da imaju i negativnu reputaciju među vršnjacima (Rielly i sur., 2006). Međutim, djeca s ADHD-om, jednako kao i sva ostala djeca, imaju vlastitu percepciju međuljudskih odnosa, što se reflektira i na odnose s vršnjacima, pri čemu su ona ipak svjesna problema i češće od ostale djece iskazuju svoje nezadovoljstvo odnosima s drugima, što posljedično vodi do općeg sniženog osjećaja socijalne samoučinkovitosti i razvoja simptoma depresivnosti i anksioznosti (Houck i sur., 2012; McQuade i Hoza, 2015; Paap i sur., 2013).

Zanimljivi su rezultati dobiveni za emocionalno funkcioniranje učenika, gdje učenici koji procjenjuju da imaju simptome predominantno nepažljivog tipa ADHDa imaju slabije razvijenu emocionalnu kompetentnost od učenika koji procjenjuju da imaju simptome predominantno hiperaktivno-impulzivnog tipa ADHD-a i onih koji nemaju ADHD. Također učenici koji procjenjuju da imaju simptome predominantno hiperaktivno-impulzivnog tipa pokazuju slabiju emocionalnu samoefikasnost od učenika koji procjenjuju da nemaju simptome ADHD-a. Simptomi hiperaktivnosti i impulzivnosti ometaju emocionalnu samoefikasnost, no nisu ključni za emocionalnu kompetenciju, gdje problem stvaraju prvenstveno simptomi nepažnje. Emocionalna kompetentnost zapravo je jedna od mjera emocionalne inteligencije, koja se odnosi na sposobnost prepoznavanja, regulacije i reagiranja u emocionalno nabijenim situacijama, na socijalno prihvatljiv način, što predstavlja značajan problem djeci s ADHD-om. To je dominantni problem u socijalnom funkcioniranju djece koja imaju izražen simptom nepažnje jer teško prepoznaju specifičnu emociju i imaju teškoća u održavanju usmjerenosti na vršnjake tijekom svakodnevnih 
interakcija (Kristensen i sur., 2014; Sjöwall i Thorell, 2014). Nadalje, snižena emocionalna samoučinkovitost kod djece koja pokazuju izraženije simptome hiperaktivnosti i impulzivnosti u skladu je i s prijašnjim istraživanjima (Felber i Knudsen, 2010) koja pokazuju da ovi problem počinju već u predškolskoj dobi kada djeca impulzivno reagiraju, na što odrasli odgovaraju korektivnim postupcima, što za dijete predstavlja novi izvor frustracija pa ih ono ili ignorira ili nastavlja obrazac impulzivnih reakcija, a to posljedično dovodi do razvoja osjećaja slabije emocionalne učinkovitosti. Ovo je posebice vidljivo kod komorbiditeta s poremećajem ophođenja s prkošenjem, gdje djeca najviše problema imaju u području regulacije negativnih emocija (Treuting i Hinshaw, 2001). Nemogućnost samoregulacije pokazatelj je slabe emocionalne samoučinkovitosti kod djece s ADHD-om, a dodatni je problem što se ova djeca koriste strategijama rješavanja problema koje se temelje na emocijama, što predstavlja teškoću u regulaciji emocionalno nabijenih situacija, pogotovo kada je riječ o negativnim emocijama (Hampel i sur., 2008).

Provedeno istraživanje, kao i tumačenje rezultata treba razmotriti s obzirom na neke metodološke nedostatke. U istraživanju su korištene isključivo metode samoprocjene te stoga ne govorimo o formalnoj dijagnozi ADHD-a, već o simptomima koji prema samoprocjeni učenika zadovoljavaju ili ne zadovoljavaju kriterije za dijagnozu ADHD-a, što nam daje ograničen uvid u problematiku funkcioniranja djece s deficitom pažnje/hiperaktivnim poremećajem. Nismo za sve pretpostavljene aspekte funkcioniranja dobili očekivane rezultate. Primjerice, za dvije varijable socijalnog funkcioniranja, broj prijatelja i socijalna samoefikasnost, nismo dobili statistički značajne razlike. Mogući razlog tome je što se zapravo radi o djeci koja su samo suspektna na ADHD, a ne o skupini koja je prošla formalnu dijagnostiku, kao i tome da jedan veći dio djece nije sudjelovao u istraživanju (oko 44\% djece), a moguće je da su to upravo djeca s izraženijim simptomima ADHD-a pa je i varijanca zbog toga smanjena. Dodatni metodološki nedostatak provedenog istraživanja je mali odaziv sudionika $(55,92 \%)$. Ipak, treba uzeti u obzir i prevalenciju ADHD-a dobivenu u prijašnjim istraživanjima koja procjenjuju da oko 5\% ima dijagnozu ADHD-a u većini kultura (APA, 2014), a uključujući i djecu koja su suspektna na ADHD, riječ je o oko 20\% djece (Balázs i Keresztény, 2014). U našemu je istraživanju $24,6 \%$, djece samo sebe procijenilo suspektnima na ADHD ili da imaju ADHD, što je u skladu s općim trendovima. To nam daje mogućnost određene generalizacije dobivenih rezultata, posebice u smjeru njihove pragmatične primjene $u$ odgojno-obrazovnom okruženju, tj. davanja smjernica za konstruiranje programa prevencije nepoželjnih oblika ponašanja i jačanja socijalnih vještina. Buduća istraživanja bi svakako trebala uključiti djecu s formalno utvrđenom dijagnozom ADHD-a, kao i veći odaziv sudionika različite dobi (od predškolske do srednjoškolske dobi). Također je poželjno i korištenje dodatnih mjera procjene (npr. procjene vršnjaka, roditelja, učitelja) kako bismo dobili potpuniji uvid u ovu problematiku. 


\section{ZAKLJUČAK}

Možemo zaključiti kako je kod djece suspektne na ADHD svakako narušeno akademsko funkcioniranje, no kada govorimo o socijalnom i emocionalnom funkcioniranju, dobiveni su slabiji efekti, odnosno nisu svi provjeravani aspekti socijalnog i emocionalnog funkcioniranja narušeni. Što su simptomi ADHD-a više izraženi, neovisno o tome što dijete nema dijagnosticiran poremećaj, veće su i posljedice na sva tri plana funkcioniranja. Nadalje, djeca suspektna na postojanje ADHD-a pokazuju nižu razinu samoefikasnosti, a svoje vještine i sposobnosti procjenjuju nedostatnima, što za posljedicu može imati odustajanje od formalnog obrazovanja. Dodatno treba razmotriti simptome nepažnje koji čine glavnu razliku na svim mjerama funkcioniranja. Nepažnja je ključna u socijalnim odnosima, tj. ona utječe na djetetove sposobnosti održavanja fokusa interesa s vršnjacima, usmjerenost na aktivnost i recipročnost u akcijama. Postojeća istraživanja, ali i praksa, dominantno su usmjereni na djecu s formalno utvrđenima (dijagnosticiranim) ADHD-om. Ono što je u kontekstu odgoja i obrazovanja problem odnosi se na djecu za koju se sumnja da imaju ADHD, ali ga nemaju formalno utvrđeno (ADHD nije dijagnosticiran, ali se sumnja na njegovo postojanje). Naime, ta djeca nisu obuhvaćena nikakvim individualnim pristupom - nemaju individualizirani program i nemaju priliku prakticirati prava kao njihovi vršnjaci s formalno utvrđenom teškoćom (koji npr. imaju pravo na pomoćnika u nastavi). Upravo zbog toga prevencijski i intervencijski programi, tipa jačanja socijalne kompetencije i poboljšanja organizacijskih vještina, imaju važnu ulogu u podizanju kvalitete života djece koja su suspektna na ADHD. Uključivanje djece u prevencijske programe koja obuhvaćaju jačanje pozitivne slike o sebi jedna je od mogućnosti reduciranja tih, nepovoljnih razvojnih scenarija, pa bi se nastojanja kliničara i pedagoških stručnjaka trebala kretati u smjeru identifikacije djece kojoj bi takav oblik podrške bio potreban.

\section{LITERATURA}

Airaksinen, E.M., Michelsson, K. i Jokela, V. (2004). The occurrence of inattention, hyperactivity, impulsivity and coexisting symptoms in a population study of 471 6-8-year old children based on the FTF (five to fifteen) questionnaire. European Child \& Adolescent Psychiatry, 13(3), 23-30.

Američka psihijatrijska udruga (2014). Dijagnostički i statistički priručnik za duševne poremećaje, peto izdanje. Jastrebarsko: Naklada Slap.

August, G.J., Ostrander, R. i Bloomquist, M.J. (1992). Attention-deficit hyperactivity disorder - an epidemiologic screening method. American Journal of Orthopsychiatry, 62, 387-396.

Balázs, J. i Keresztény, Á. (2014). Subthreshold attention deficit hyperactivity in children and adolescents: a systematic review. European Child and Adolescent Psychiatry, 23, 393-408. 
Barkley, R.A. (2015). Emotional dysregulation is a Core Component of ADHD. U: R.A. Barkley (ur.), Attention-Deficit Hyperactivity Disorder: A Handbook for Diagnosis and Treatment (str. 122-166). New York \& London: The Guilford Press.

Becker, A., Steinhausen, H.C., Baldursson, G., Dalsgaard, S., Lorenzo, M.J., Ralston, S.J., Döpfner, M., Rothenberger, A., Baldursson, G., Coghill, D., Curatolo, P., Falissard, B., Hervas, A., Le Heuzey, M.F., Nøvik, T.S., Pereira, R.R., Preuss, U., Rasmussen, P., Riley, A.W., Spiel, G. i Vlasveld, L. (2006). Psychopathological screening of children with ADHD: Strengths and Difficulties Questionnaire in a pan-European study. European Child \& Adolescent Psychiatry, 15(1), i56-i62.

Biederman, J., Petty, C.R., Evans, M., Small, J. i Faraone, S.V. (2010). How persistent is ADHD? A controlled 10-year follow-up study of boys with ADHD. Psychiatry Research, 177, 299-304.

Bussing, R., Mason, D.M., Bell, L., Porter, P. i Garvan, C. (2010). Adolescent outcomes of childhood attention-deficit/hyperactivity disorder in a diverse community sample. Journal of the American Academy of Child and Adolescent Psychiatry, 49, 595-605.

Bussing, R., Porter, P., Zima, B.T., Mason, D., Garvan, C. i Reid, R. (2012). Academic outcome trajectories of students with ADHD: does exceptional education status matter? Journal of Emotional and Behavioral Disorders, 20, 131-143.

Coghill, D., Spiel, G., Baldursson, G., Döpfner, M., Lorenzo, M.J., Ralston, S.J. I Rothenberger, A. (2006). Which factors impact on clinician-rated impairment in children with ADHD? European Child \& Adolescent Psychiatry, 15(1), i30-i37.

Corkum, P., Corbin, N. i Pike, M. (2010). Evaluation of a School-Based Social Skills Program for Children With Attention-Deficit/Hyperactivity Disorder. Child \& Family Behavior Therapy, 32(2), 139-151.

Defoe, I.N., Farrington, D.P. i Loeber, R. (2013). Disentangling the relationship between delinquency and hyperactivity, low achievement, depression, and low socioeconomic status: Analysis of repeated longitudinal data. Journal of Criminal Justice, 41(2), 100-107.

Diener, M.B. i Milich, R. (1997). Effects of positive feedback on the social interactions of boys with attention deficit hyperactivity disorder: a test of the self-protective hypothesis. Journal of Clinical Child Psychology, 26(3), 256-265.

Dunn, P.B. i Shapiro, S.K. (1999). Gender differences in the achievement goal orientation of ADHD children. Cognitive Therapy and Research, 23, 327-344.

DuPaul, G.J. i Langberg, J.M. (2015). Educational Impairments in Children with ADHD. U: R.A. Barkley (ur.), Attention-Deficit Hyaperactivity Disorder: A Handbook for Diagnosis and Treatment (str. 234-263). New York \& London: The Guilford Press.

Elia, J., Ambrosini, P. i Berrettini, W. (2008). ADHD characteristics: I. Concurrent co-morbidity patterns in children and adolescents. Child and Adolescent Psychiatry and Mental Health Journal, 2(1), 15-23.

Escobar, R., Soutullo, C.A., Hervas, A., Gastaminza, X., Polavieja, P. i Gilaberte, I. (2005). Worse quality of life for children with newly diagnosed attention-deficit/hyperactivity disorder, compared with asthmatic and healthy children. Pediatrics, 116(3), e364-e369.

Faraone, S.V., Sergeant, J., Gillberg, C. i Biederman, J. (2003). The worldwide prevalence of ADHD: is it an American condition? World Psychiatry, 2(2), 104-113.

Felber, M. i Knudsen, K. (2010). Hyperaktive verhaltenskreative Kinder in Kindergarten und Schule. U: J. Hofmeister i A. Kröhnert (ur.), ADHS: Diagnostik und Hilfen für 
betrodffene Kinder und Jugendliche und ihre Eltern (str. 249-267). Köln: Die Kinderschutz Zentren. Pribavljeno 10.3. 2016. s http://www.khbrisch.de/files/adhs_kinderschutz_stuttgart_final.pdf

Fergusson, D.M., Boden, J.M. i Horwood, L.J. (2010). Classification of behavior disorders in adolescence: scaling methods, predictive validity, and gender differences. Journal of Abnormal Psychology, 119, 699-712.

Frazier, T.W., Youngstrom, E.A., Glutting, J.J., i Watkins, M.W. (2007). ADHD and achievement: Meta-analysis of the child, adolescent, and adult literatures and a concomitant study with college students. Journal of Learning Disabilities, 40, 49-65.

Gropper, R.J. I Tannock, R. (2009). A pilot study of working memory and academic achievement in college students with ADHD. Journal of Attention Disorder, 12(6), 574-581.

Hampel, P., Manhal, S., Roos R. i Desman C. (2008). Interpersonal coping among boys with ADHD. Journal of Attention Disorder, 11, 427-450.

Hong, S.B., Dwyer, D., Kim, J.W., Park, E.J., Shin, M.S., Kim, B.N., Yoo, H.J., Cho, I.H., Bhang, S.Y., Hong, Y.C., Pantelis, C. i Cho, S.C. (2014). Subthreshold attention-deficit/ hyperactivity disorder is associated with functional impairments across domains: a comprehensive analysis in a large-scale community study. European Child and Adolescent Psychiatry, 23(8), 627-636.

Honos-Webb, L. (2010). The Gift of ADHD: How to Transform Your Child's Problems into Strengths Paperback. Oakland CA: New Harbinger Publications, Inc.

Houck, G., Kendall, J., Miller, A., Morrell, P. i Wiebe, G. (2012). Self-concept in Children and Adolescents with ADHD. Journal of Pediatric Nursing, 26(3), 239-247.

Jogsan, Y.A. (2013). Emotional Maturity and Adjustment in ADHD Children. Journal of Psychology and Psychotherapy, 3(2), 1-4.

Kocijan-Hercigonja, D. (2008). Poremećaj pozornosti s hiperaktivnošću (ADHD). Pribavljeno 15.4.2009. s www.psihonet.com

Kristensen, H.A., Parker, J.D.A, Taylor, R.N., Keefer, K.V., Kloosterman, P.H. i Summerfeldt, L.J. (2014). The relationship between trait emotional intelligence and ADHD symptoms in adolescents and young adults. Personality and Individual Differences, $65,36-41$.

Lachenmeier, H. (2014). Selbstwertwahrnehmung bei ADHS Erwachsener. Schweizer Archiv für Neurologie, Psychiatrie und Psychotherapie, 165(2), 47-53.

Mayer, J. D., \& Salovey, P. (1997). What is emotional intelligence? U: P. Salovey i D. J. Sluyter (Ur.), Emotional development and emotional intelligence: Educational implications (str. 3-34). New York: Harper Collins.

Mayes, S.D., Calhoun, S.L. i Crowell, E.W. (2000). Learning disabilities and ADHD: overlapping spectrum disorders. Journal of Learning Disabilities, 33(5), 417-424.

McQuade, J.D. i Hoza, B. (2015). Peer relationships of Children with ADHD. U: R. A. Barkley (Ur.), Attention-Deficit Hyperactivity Disorder: A Handbook for Diagnosis and Treatment (str. 288-305). New York \& London: The Guilford Press.

Meltzer, H., Gatward, R., Goodman, R. i Ford, T. (2003) Mental health for children and adolescents in Great Britain. International Review of Psychiatry, 15, 185-187.

Mikami, A.Y. i Normand, S. (2015). The Importance of Social Contextual Factors in Peer Relationships of Children with ADHD. Current Developmental Disorders Report, 2(1), 30-37. 
Mrug, S., Hoza, B., Gerdes, A.C., Hinshaw, S., Arnold, L.E., Hechtman L. i Pelham, W.E. (2009). Discriminating between children with ADHD and classmates using peer variables. Journal of Attention Disorder, 12, 372-389.

Norén Selinus, E., Molero,Y., Lichtenstein, P., Anckarsäter, H., Lundström, S., Bottai, M. i Hellner Gumpert, C. (2016). Subthreshold and threshold attention deficit hyperactivity disorder symptoms in childhood: psychosocial outcomes in adolescence in boys and girls. Acta Psychiatrica Scandinavica, 134(6), 533-545.

Norvilitis, J.M., Sun, L. i Zhang, J. (2010). ADHD symptomatology and adjustment to college in China and the United States. Journal of Learning Disabilities, 43, 86-94.

Norwalk, K., Norvilitis, J. i MacLean, M.G. (2009). ADHD symptomatology and its relationship to factors associated with college adjustment. Journal of Attention Disorders, 13, 251-258.

Owens, E.B., Hinshaw, S.P., Lee, S.S. i Lahey, B.B. (2009). Few girls with childhood attention-deficit/hyperactivity disorder show positive adjustment during adolescence. Journal of Clinical Child and Adolescent Psychology, 38, 132-143.

Paap, M.C., Haraldsen, I.R., Breivik, K., Butcher, P.R., Hellem, F.M. i Stormark, K.M. (2013). The Link between Peer Relations, Prosocial Behavior, and ODD/ADHD Symptoms in 7-9-Year-Old Children. Pribavljeno 12.2.2016. s http://www.hindawi.com/ journals/psychiatry/2013/319874/

Pagani, L., Vitaro, F., Tremblay, R., McDuff, P., Japel, C. i Larose, S. (2008b). When predictions fail: the case of unexpected pathways toward high school dropout. Journal of Social Issues, 64, 175-194.

Polanczyk ,G., de Lima, M.S., Horta, B.L., Biederman, J., Rohde, L.A. (2017). The worldwide prevalence of ADHD: a systematic review and metaregression analysis. American Journal of Psychiatry, 164(6), 942-948.

Raboteg-Šarić, Z. (2002). E -upitnik: skala emocionalne empatije. U: K. Lacković-Grgin, A. Proroković, V. Ćubela i Z. Penezić (Ur.), Zbirka psihologijskih skala i upitnika (str. 44-49). Zadar: Filozofski fakultet u Zadru.

Rafalovich, A. (2008). Framing ADHD Children: A Critical Examination of History, Discourse, and Everyday Experience of Attention Deficit/Hyperactivity Disorder. Maryland, US: Lexington Books.

Rielly, N.E., Craig, W.M. i Parker, K.C. (2006). Peer and parenting characteristics of boys and girls with subclinical attention problems. Journal of Attention Disorders, 9, 598606.

Schwenck, C., Schmitt, D., Sievers, S., Romanos, M., Warnke, A. i Schneider, W. (2011). Kognitive und emotionale Empathie bei Kindern und Jugendlichen mit ADHS und Störung des Sozialverhaltens. Zeitschrift für Kinder- und Jugendpsychiatrie und Psychotherapie, 39(4), 265-276.

Sjöwall, D. i Thorell, L.B. (2014). Functional Impairments in Attention Deficit Hyperactivity Disorder: The Mediating Role of Neuropsychological Functioning. Developmental Neuropsychology, 39(3), 187-204.

Steinhausen, H.C., Nøvik, T.S., Baldursson, G., Curatolo, P., Lorenzo, M.J., Pereira, R.R., Ralston, S. J., Rothenberger, A., Coghill, D., Dalsgaard, S., Döpfner, M., Falissard, B., Hervas, A., Le Heuzey, M.F., Nøvik, T.S., Preuss, U., Rasmussen, P., Riley, A.W., 
Rothenberger, A., Spiel, G.. i Vlasveld, L. (2006). Co-existing psychiatric problems in ADHD in the ADORE cohort. European Child and Adolescent Psychiatry, 15(1), i25i29.

Takšić, V. (2002). Upitnici emocionalne kompetentnosti. U: K. Lacković-Grgin, A. Proroković, V. Ćubela i Z. Penezić (Ur.), Zbirka psihologijskih skala $i$ upitnika (str. 27-45). Zadar: Filozofski fakultet u Zadru.

Todd, R.D., Sitdhiraksa, N., Reich, W., Ji, T.H., Joyner, C.A., Heath, A.C. i Neuman, R.J. (2002). Discrimination of DSM-IV and latent class attention-deficit/hyperactivity disorder subtypes by educational and cognitive performance in a population-based sample of child and adolescent twins. Journal of the American Academy of Child and Adolescent Psychiatry, 41, 820-828.

Treuting, J.J. i Hinshaw, S.P. (2001). Depression and self-esteem in boys with attentiondeficit/hyperactivity disorder: Associations with comorbid aggression and explanatory attributional mechanisms. Journal of Abnormal Child Psychology, 29, 23-39.

Turnbull, A., Turnbull, R., i Wehmeyer, M. (2010). Exceptional lives: Special education in today's schools (6th ed.). Columbus, $\mathrm{OH}$ : Pearson.

Velki, T. (2012). Priručnik za rad s hiperaktivnom djecom u školi. Jastrebarsko: Naklada Slap.

Vulić-Prtorić, A. (2006). Skala hiperaktivnosti - impulzivnosti - pažnje - HIP. U: V. Ćubela Adorić, A. Proroković, Z. Penezić i I. Tucak (ur.), Zbirka psihologijskih skala i upitnika - Svezak 3 (str. 41-49). Zadar: Sveučilište u Zadru.

Vulić-Prtorić, A. i Sorić, I. (2006). Upitnik samoefikasnosti za djecu-SEQ-C. U: V. Ćubela Adorić, A. Proroković, Z. Penezić i I. Tucak (ur.), Zbirka psihologijskih skala i upitnika - Svezak 3 (str. 87-93). Zadar: Sveučilište u Zadru.

Wender, P.H., Wolf, L.E. i Wasserstein, J. (2001). Adults with ADHD: An overview. Annals of the New York Academy of Sciences, 93(1), 1-16.

Weyandt, L.L. i DuPaul, G.J. (2008). ADHD in college students: Developmental Findings. Developmental Disabilities Research Reviews, 14, 311-319.

Whalen, C. K., Jamner, L. D., Henker, B., Delfino, R. J. i Lozano, J. M. (2002). The ADHD spectrum and everyday life: experience sampling of adolescent moods, activities, smoking, and drinking. Child Development, 73, 209-227.

Wu, S.Y. i Gau S.S.F. (2013). Correlates for academic performance and school functioning among youths with and without persistent attention-deficit/hyperactivity disorder. $R e$ search in Developmental Disabilities, 34(1), 505-515.

Young, S., Heptinstall, E., Sonuga-Barke, E.J.S., Chadwick, O. i Taylor, E. (2005). The adolescent outcome of hyperactive girls: Self-report of psychosocial status. Journal of Child Psychology and Psychiatry, 46, 255-262.

Zajacova, A., Lynch, S.M. i Espenshade, T.J. (2005). Self-efficacy, stress, and success in college. Research in Higher Education, 46, 677-706. 


\title{
ACADEMIC, SOCIAL AND EMOTIONAL FUNCTIONING OF CHILDREN AT RISK FOR DEVELOPMENT OF ADHD
}

\begin{abstract}
Summary
Numerous studies have shown that children with ADHD express problems in academic, social, and emotional functioning. However, there are very few studies dealing with children with subthreshold ADHD, where such deviations could be indicative for the consequential development of the disorder, and as such are very important in the organization of preventive programs. The goal of the research was to test the academic (academic achievement, academic self-efficacy), social (number of friends, peer acceptance, social self-efficacy) and emotional (empathy, emotional competence, emotional self-efficacy) functioning of children with subthreshold ADHD. The study included 492 students in the $4^{\text {th }}, 6^{\text {th }}$ and $8^{\text {th }}$ grades (average age $\mathrm{M}=12.72, \mathrm{SD}=1.62$ ). The students were divided into 3 groups based on the self-assessment of symptoms according to DSM-V, wherein $11 \%(\mathrm{~N}=55)$ of students self-evaluated having subthreshold symptoms for ADHD and $13.6 \%(\mathrm{~N}=68)$ self-evaluated having symptoms for a diagnosis of ADHD. These two groups were considered to be suspect for ADHD, while other students did not report having symptoms of ADHD $(75.4 \%, \mathrm{~N}=377)$. The following instruments were used: Scale of Hyperactivity-Impulsivity-Attention (HIP; Vulić-Prtorić, 2006), Self-efficacy Questionnaire for Children (SEQ-C, Vulić-Prtorić \& Sorić, 2006), Questionnaire of Emotional Competence (UEK-45; Takšić, 2002), Emotional Empathy Scale of E-Questionnaire (Raboteg-Šarić, 2002). The students were also asked to self-evaluate peer acceptance, the number of friends they have and to give information about school success. The results showed that children suspected for ADHD have a deficit in academic functioning (both aspects, $F_{(2,490)}$ academic achievement $=3.87, p=0.021, \omega=0.11 ; F_{(2,490)}$ academic self-efficacy $=23.46, p=0.000$, $\omega=0.29$ ), while social and emotional functioning deviations were found to have only one aspect $\left(F_{(2,490)}\right.$ peer acceptance $=4.35, p=0.013, \omega=0.12 ; F_{(2,490)}$ emotional self-efficacy $=6.76, p=0.001, \omega=0.15)$. We can conclude that children suspected for ADHD certainly have a deficit in academic functioning, but when we talk about social and emotional functioning these differences are minor and only relate to some examined aspects which should be further investigated in future studies. Future prevention programs should focus primarily on assistance in school adjustment, but also in the development of social skills necessary for the creation of close peer relationships and to the development of the child's ability to cope with negative emotions.
\end{abstract}

Key words: ADHD, academic functioning, social development, emotional development, primary school students 